Abstracta Iranica Iranica

Revue bibliographique pour le domaine irano-aryen

Volume 40-41 | 2019

Comptes rendus des publications de 2017-2018

\title{
David Stronach. "On the Birth of Early Achaemenid Monumental Art at Pasargadae"
}

\section{Astrid Nunn}

\section{(2) OpenEdition}

1 Journals

\section{Édition électronique}

URL : http://journals.openedition.org/abstractairanica/49349

DOI : 10.4000/abstractairanica.49349

ISBN : 1961-960X

ISSN : 1961-960X

Éditeur :

CNRS (UMR 7528 Mondes iraniens et indiens), Éditions de l'IFRI

Référence électronique

Astrid Nunn, "David Stronach. "On the Birth of Early Achaemenid Monumental Art at Pasargadae" », Abstracta Iranica [En ligne], Volume 40-41 | 2019, document 51, mis en ligne le 30 octobre 2019, consulté le 23 avril 2021. URL : http://journals.openedition.org/abstractairanica/49349 ; DOI : https:// doi.org/10.4000/abstractairanica.49349

Ce document a été généré automatiquement le 23 avril 2021.

Tous droits réservés 


\title{
David Stronach. "On the Birth of Early Achaemenid Monumental Art at Pasargadae"
}

\author{
Astrid Nunn
}

\section{RÉFÉRENCE}

David Stronach. "On the Birth of Early Achaemenid Monumental Art at Pasargadae" in Friedhelm Pedde, Nathanael Shelley (eds.). Assyromania and More. In Memory of Samuel M. Paley. Münster: Zaphon, 2018, p. 353-359, (marru; B.d 4)

1 Les sources d'inspiration pour l'art achéménide sont variées, nombreuses et omniprésentes (all pervasive). Parmi celles-ci, l'art assyrien est la plus importante, à commencer pour Cyrus le Grand qui se considérait comme l'héritier du pouvoir assyrien. En conséquence l'A. pense Pasargades dans une optique assyrienne, essentiellement marquée par le palais de Khorsabad. Ainsi les ouvertures de la Porte $\mathrm{R}$ sont pourvues de gardiens (taureaux ailés). Les démons (lulal, ugallu, apkallu) indiquent que ces créatures avaient la même importance protectrice qu'en Assyrie. Enfin le génie ailé portant la couronne $\mathrm{hm}-\mathrm{hm}$ pourrait avoir été conçu après la prise de Babylone, ce qui donnerait également un point de référence dans la chronologie de la construction. 


\section{AUTEURS}

\section{ASTRID NUNN}

Université de Munich 